Sebastian Chojnacki

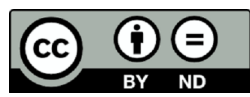

\title{
Sowiecka sztuka operacyjna w latach 1940-1941
}

Zarys treści: Artykuł prezentuje rozwój sowieckiej myśli operacyjnej, poczynając od pierwszego etapu jej kreowania w latach dwudziestych XX wieku. Następnie opisuje skutki Wielkiej Czystki dla ewolucji sowieckiej myśli wojskowej i samej Armii Czerwonej. Ostatnią rzeczą jest analiza sowieckiego planowania strategicznego w kontekście wojny ofensywnej przeciw III Rzeszy z punktu widzenia sztuki operacyjnej jej przełożenia na strategię.

Outline of content: The article presents the evolution of the Soviet operational warfare since its initial phase in the 1920s, followed by a characterisation of the impact of the Great Purge on the evolution of the Soviet military doctrine and the Red Army itself. Finally, Soviet strategic planning is analysed in the context of the offensive war with the Third Reich from the point of view of operational art and its translation into strategy.

Słowa kluczowe: sowiecka sztuka operacyjna, sowiecka taktyka, armia uderzeniowa, Armia Czerwona w czasie II wojny światowej, Wielka Czystka.

Keywords: Soviet operational art, Soviet tactic, shock army, Red Army in world war II, Great Purge.

Wydarzenia związane z agresją Niemiec na Związek Sowiecki doczekały się niezliczonej ilości publikacji ${ }^{1}$. Cała dyskusja związana $\mathrm{z}$ wydarzeniami poprzedzającymi

1 Najważniejsze prace w języku polskim: C. Pleshakow, Szaleństwo Stalina. Pierwsze 10 dni wojny na froncie wschodnim, Warszawa 2005, W. Suworow, Dzień „M”, Poznań 2008, W. Bieszanow, Pogrom pancerny 1941, przeł. S. Kędzierski, Warszawa 2009, M. Sołonin, Na uśpionych lotniskach..., przeł. A. Pawłowska, Poznań 2009, W. Suworow, Ostatnia defilada, przeł. A. Pawłowska, Poznań 2009, W. Suworow, Ostatnia republika, przeł. A. Bobrowicki, D. Majeńczyk, Poznań 2009, W. Suworow, Klęska, przeł. A. Pawłowska, Poznań 2010. Jeśli chodzi o literaturę rosyjską poświęconą tej tematyce, to jest ona olbrzymia, dlatego wymienię tylko pozycje najczęściej cytowane w znanych mi publikacjach: 1941 год - уроки и выводы, Москва 1992, М. И. Мельтюхов, Упущенный шанс Сталина. Советский 
22 czerwca 1941 r. rozpoczęła się od książki Lodołamacz² Wiktora Suworowa. Po raz pierwszy przedstawiona została teza o prewencyjności niemieckiego ataku. Kolejną publikacją, która starała się rzucić nowe światło na pierwszy okres wojny sowiecko-nazistowskiej była książka Marka Sołonina 22 czerwca 1941 czyli jak zaczęła się Wielka Wojna Ojczyźniana ${ }^{3}$. Autor stawiał w niej odważniejszą tezę. Dokonując analizy trzech uderzeń wykonanych przez Armię Czerwoną w pierwszych dniach wojny sowiecko-niemieckiej 1941 r., doszedł do zaskakującego wniosku dotyczącego niepowodzenia. Mianowicie, nastąpiła masowa dezercja w szeregach armii chłopsko-robotniczej.

Moim osobistym zainteresowaniem cieszył się temat sowieckiej myśli wojskowej, zarówno przed Wielką Czystką, jak i po niej, a przede wszystkim pytanie, czy poglądy z końca lat dwudziestych nadal obowiązywały i jaki był ich wpływ na planowanie strategiczne w latach 1940-41. Myśl wojskowa w Związku Sowieckim w latach dwudziestych i trzydziestych wyznaczała standardy światowe. Przykładem tego jest twórczość dwóch teoretyków: Georgija Issersona i Władimira Triandafiłłowa.

Kolejną kwestią jest „problem” Wielkiej Czystki. Pozwoliłem sobie nazwać to zagadnienie problemem. Po pierwsze, z powodu braku możliwości określenia jej dalekosiężnych skutków. Po drugie, jest to sprawa bez precedensu, eliminacja całego wyższego kierownictwa armijnego i po trzecie, nie ma badań porównujących problem z fachowością korpusu oficerskiego Wehrmachtu i US Army. Wymienione siły zbrojne, podobnie jak Armia Czerwona, rozwinęły się błyskawicznie pod względem liczebności. Warto byłoby odpowiedzieć na pytanie, jaka była skala braków kadrowych we wszystkich trzech armiach? Nie oznacza to, że brak dobrych publikacji na temat Wielkiej Czystki. Ostatnia część poświęcona jest posiedzeniu Głównej Rady Wojennej i wyższej kadry dowódczej Armii Czerwonej w grudniu 1940 r. i planom Józefa Stalina po listopadzie, w tym samym okresie.

W polskiej historiografii teoria głębokich operacji nie cieszyła się do tej pory szczególnym zainteresowaniem. Szereg autorów porusza tę kwestię w kilku publikacjach poświęconych szerszym studiom. Większa liczba prac wprowadzających nowe poglądy pojawiła się w książkach angielskojęzycznych. Najlepszym w tej chwili studium na temat głębokich operacji jest książka Richarda W. Harrisona, Architect of Soviet Victory in Word War II. The Life and Theories of G. S. Isserson ${ }^{4}$. Wskazuje ona właśnie na Georgija Issersona jako głównego twórcę koncepcji głębokich operacji. Jest ona w pewnym sensie krytyką wcześniejszej pracy Harrisoma, The Russian Way of War. Operational Art, 1904-19405. Z kolei w niej Triandafiłłow jest uważany za głównego architekta doktryny. Inny charakter ma książka Shimona

Союз и борьба за Европу: 1939-1941, istnieje także szereg opublikowanych artykułów w zbiorach pod nаzwą Правда Виктора Суворова, wydawanych w 1. 2007-2012. Zob. też przypisy 2,3,12,14,15,17,19.

2 W. Suworow, Lodołamacz, przeł. A. Mietkowski, P. Halbersztat, Poznań 2008.

3 M. Sołonin, 22 czerwca 1941 czyli jak zaczęła się Wielka Wojna Ojczyźniana, przeł. T. Lisiecki, Poznań 2007.

4 R. W. Harrisom, Architect of Soviet Victory in Word War II. The Life and Theories of G. S. Isserson, Jefferson 2010.

5 R. W. Harrisom, The Russian Way of War. Operational Art, 1904-1940, Lawrence 2001. 
Naveha, In Pursuit of Military Excellence. The Evolution of Operational Theory ${ }^{6}$. Podstawą do rozważań zarówno nad głębokimi operacjami, jak i nad Blitzkriegiem, jest teoria systemu uniwersalnego Bertalanffiego. Z prac sowieckich teoretyków wybrałem dwie o szczególnym znaczeniu. Pierwszą jest Charakter operacji wspótczesnych armii ${ }^{7}$ Władimira Triandaffiłłowa, a drugą Ewolucja sztuki operacyjnej ${ }^{8}$ Georgija Issersona. Obie są fundamentalnymi pozycjami, poruszającymi problem sztuki operacyjnej. W celu pokazania poglądów obu teoretyków przedstawiłem jeden z podpunktów Tymczasowego regulaminu polowego ${ }^{9} \mathrm{z}$ roku 1936. W kwestii Wielkiej Czystki podstawą jest książka Pawła Piotra Wieczorkiewicza Łańcuch śmierci. Czystka w Armii Czerwonej 1937-193910. Treści zawarte w tym potężnym, tysiącstronicowym opracowaniu uzupełniłem danymi zaczerpniętymi z trzech innych dobrych publikacji. Pierwszą jest książka Władimira Bieszanowa, Kadry decyduja o wszystkim ${ }^{11}$, a pozostałymi dwiema - prace Rogera r. Reesa, Czerwoni Dowódcy. Korpus Oficerski Armii Czerwonej ${ }^{12}$ i The Soviet Military Experience. A history of Soviet Army 1917-1991 ${ }^{13}$. Obaj autorzy wychodzą z podobnego założenia. Uważają, że fachowość sowieckiego korpusu oficerskiego przed czystką była niska. Aby pokrótce przedstawić zwiększenie liczebności Armii Czerwonej, oparłem się na pracach dwóch historyków: Bogdana Musiała ${ }^{14}$ i Olega Kena ${ }^{15}$.

Źródłem do badania sowieckiej sztuki operacyjnej w okresie 1940-1941 jest stenogram z posiedzenia Głównej Rady Wojennej i wyższej kadry dowódczej Armii Czerwonej, wydany w dwóch tomach ${ }^{16}$. Na tej naradzie dyskutowano o modernizacji armii i prowadzeniu walki, w oparciu o doświadczenia kampanii z lat 19391940. Drugim źródłem jest zbiór dokumentów 1941 god $^{17}$, wydany w dwóch tomach. Są tam bardzo cenne dokumenty poświęcone sowieckim planom wojennym. Tym wartościowsze, że część z nich jest nadal utajnionych. Utrudnieniem w korzystaniu z powyższego zbioru jest brak konkretnych dat wystawienia dokumentów, np. „nie wcześniej niż 15 maja”. Z tego powodu trzeba korzystać ze zbioru, w którym

6 S. Naveh, In Pursuit of Military Excellence. The Evolution of Operational Theory, Londyn 2004.

7 В. К. Триандафиллов, Характер операций современных армий, Москва 1936.

8 Г. С. Иссерсон, Эволюиия оперативного искусства, Москва 1937.

9 Временный полевой устав РККА (Ри-36), Moskwa 1937.

10 P. Wieczorkiewicz, Łańcuch śmierci. Czystka w Armii Czerwonej 1937-1939, Warszawa 2001.

11 W. Bieszanow, Kadry decyduja o wszystkim, przeł. A. Palacz, Warszawa 2009.

12 R. R. Reese, Czerwoni Dowódcy. Korpus Oficerski Armii Czerwonej, przeł. S. Kędzierski, Warszawa 2010.

13 R. R. Reese, The Soviet Military Experience. A history of Soviet Army 1917-1991, Routledge 2000.

14 B. Musiał, Na zachód po trupie Polski, przeł. M. Falkowski, Warszawa 2009.

15 О. Кен, Мобилизачионное планирование и Политические решения, Москва 2008.

16 Armia Czerwona w przededniu najcięższej próby (Materiały z posiedzenia Głównej Rady Wojennej i wyższej kadry dowódczej Armii Czerwonej w dniach 23-31 grudnia 1940 roku), wstęp, tłum. i oprac. J. Budziński, C. Grzelak, Z. Matuszak, Warszawa 2006; Armia Czerwona w latach 1940-1941 (Materiały z posiedzenia Głównej Rady Wojennej i wyższej kadry dowódczej Armii Czerwonej w dniach 23-31 grudnia 1940 roku), wstęp, tłum. i oprac. J. Budziński, C. Grzelak, Z. Matuszak, Warszawa 2007.

17 Россия - ХХ век. Документы. 1941 г., Москва 1998. 
opublikowano wpisy wejść do gabinetu Józefa Stalina ${ }^{18}$. Dodatkowo przy opracowywaniu akt opublikowanych w zbiorze dokumentów 1941 god korzystałem z prac Marka Sołonina ${ }^{19}$, rosyjskiego historyka-amatora, który dokonał najlepszej, moim zdaniem, polskojęzycznej interpretacji tych materiałów.

„Nazywamy operacją ten akt wojny, w czasie którego walczące bez przerwy jednostki są kierowane $\mathrm{w}$ wybrany region teatru wojennego, w celu osiągnięcia określonych celów" ${ }^{20}$. Jest to jedna z pierwszych prób określenia, czym jest sztuka operacyjna. Głos w dyskusji, poruszającej kwestie umiejscowienia jej jako pośredniego szczebla między strategią i taktyką, zabrał Aleksander Swieczin w swoim fundamentalnym dziele Strategia. Swoje poglądy na temat sztuki operacyjnej rozwinął w dziele Integralne zrozumienie sztuki operacyjnej, w którym pisze: „(...) strategia i taktyka są rozdzielone przez pośredni szczebel - sztukę operacyjną; myślimy, że pozostawienie starego podziału na strategię i taktykę, obecnie jest absurdem, ponieważ (...) generalnie bitwa, która dawniej służyła jako podstawa dla tego podziału, już nie istnieje. Wierzymy, że każda z części, na które dzieli się sztuka wojenna, musi zawierać wewnętrzną spójność (...). Dla taktyki, takim polem są nowoczesne realia bitwy (...). Dla sztuki operacyjnej organizacja oddzielnych działań taktycznych dla operacji, poczynając od operacji jako całości. Na końcu, zadaniem grupowania operacji, do osiągnięcia politycznych celów wojny powierzone strategii”21.

Jednym ze zwolenników Sweczina był Warfołomjew. W 1928 r. opublikował on artykuł pod tytułem Strategia na tle akademickim. Czytamy w nim: „studia nad operacją wyszły poza obrębie taktyki, która całościowo zajmowała się studiowaniem jednej bitwy, ale nie wielu. Nowoczesna operacja, grupując bitwy, kompleksowym aktem; oznaczającym całość manewru i bitwy w wyznaczonym sektorze teatru działań wojennych, skierowanych w celu osiągnięcia sukcesu całkowitego, finalnego sukcesu w danym czasie kampanii. Przeprowadzenie operacji jest poza zasięgiem taktyki. Całościowo stała się sztuką operacyjną. Dlatego formuła składająca się z dwóch części 'taktyka-strategia', staje się formułą składającą się z trzech części:

taktyka sztuka operacyjna strategia

walka operacja wojna"22.

O umiejscowieniu sztuki operacyjnej jako pośredniego szczebla między taktyką i strategią można mówić od roku $1928^{23}$.

Lata 20. były bardzo płodne w dzieła o tematyce wojskowej stojące na wysokim poziomie. Z ważniejszych warto wymienić: wspominaną wcześniej Strategię Swie-

18 На приеме у Сталина. Тетради (журналы) записей лии, принятых И. В. Сталиным (1924-1953 г2.), Москва 2008.

19 M. Sołonin, 23 czerwca. Dzień „M”, przeł. J. Redlich, Poznań 2008; M. Sołonin, 25 czerwca. Głupota czy agresja ?, przeł. J. Redlich, Poznań 2011; M. Sołonin, Nic dobrego na wojnie, przeł. A. Pawłowska, Poznań 2011.

20 Cyt. za: S. Naveh, op. cit., s. 182.

21 Cyt. za: R. W. Harrisom, The Russian Way..., s. 140.

22 Cyt. za: ibidem.

23 Ibidem, s. 141. 
czina, dzieło zbiorowe Tuchaczewskiego, Warfołomiejewa i Szilowskiego Operacja Armii: praca dowódcy i pole kierowania, Sztuka operacyjna w wojnie pozycyjnej Kapustina, Kolejne operacje w odniesieniu do doświadczeń Marny i Wisły Mowczina, Ofensywna operacja armii, jako części frontu Kolenkowskiego, i najważniejsza pozycja tego okresu Charakter operacji współczesnych armii Władimira Triandafiłłowa ${ }^{24}$.

Ostatnia z wymienionych pozycji jest najlepszym opisem teorii głębokich operacji w początkowym okresie jej powstawania. Jako pierwszy Triandafiłłow używa pojęcia „armia uderzeniowa”. W swoim dziele charakteryzuje ją jako: „(...) może samodzielnie zorganizować serię kolejnych operacji od początku do końca. Ma posiadać takie środki, które pozwoliłyby jej przezwyciężyć wszelki opór nieprzyjaciela na początku i w trakcie trwania operacji”25. Drugą zasługą Triandafiłłowa było określenie głębokości obrony nieprzyjaciela. Głębokość obrony taktycznej wyliczył na 8 do $10 \mathrm{~km}$, do której przyporządkowano rezerwy korpusu. Operacyjną obronę podciągnął pod rezerwy armijne, ustalając jej głębokość na 25 do $35 \mathrm{~km}$. Strefa obrony frontu lub grupy armii miała mieć głębokość 80 do 100 km²6. Kolejną kwestią, która nie cieszyła się aprobatą Triandafiłlowa, była idea ofensywy o wąskim froncie. Był to najczęstszy rodzaj działań zaczepnych na dużą skalę w czasie pierwszej wojny światowej, jedyny wyjątek stanowiła ofensywa Brusiłowa w 1916 roku. Jako dowód, Triandafiłłow podawał ofensywę Ludendorfa w marcu 1918 roku. Niemcy wykonali uderzenie na froncie o szerokości $80 \mathrm{~km}$, przy całkowitej długości frontu $730 \mathrm{~km}$. Szerokość natarcia wynosiła zaledwie $11 \%$ całej linii frontu ${ }^{27}$. Ponadto zalecał, by przy przełamaniu linii okopów realizować dwa podstawowe założenia. Po pierwsze maksymalnie koncentrować siły w miejscu przełamania, a po drugie zostawić rezerwę, by powodzenie taktyczne zamienić w powodzenie operacyjne ${ }^{28}$. Triandafiłłow jako pierwszy wprowadzał pojęcie „grupy przełamania” $i$,grupy manewrowej” ${ }^{29}$. Druga $z$ wymienionych grup miała spenetrować obronę nieprzyjaciela na głębokość 35 do 50 km, okrążyć go i zniszczyć. Podsumowując, Władimir Triandafiłłow poprzez analizę rozwoju współczesnych mu armii określił dymensję, pryncypia i podjął próbę scharakteryzowania tego nowego poziomu w sztuce wojennej ${ }^{30}$. Jednak to nie on był twórcą koncepcji głębokich operacji. By połączyć swoje poglądy w jedną spójną doktrynę zabrakło mu czasu. Zginął w wypadku lotniczym 12 lipca 1931 roku $^{31}$.

W tym samym roku w Akademii im. Frunzego powstał wydział operacyjny. Pierwszym jego szefem został Wakulicz, a na swojego zastępcę powołał Georgija Issersona. W niedługim czasie ten ostatni awansował na szefa całego wydziału ${ }^{32}$.

24 Ibidem.

25 В. К. Триандафиллов, op. cit., s. 124.

26 R. W. Harrisom, The Russian Way..., s. 144.

27 Ibidem, s. 145.

28 Ibidem, s. 146-147.

29 Ibidem, s. 148.

30 S. Naveh, op. cit., s. 186.

31 R. W. Harrisom, Architect of Soviet..., s. 93.

32 Ibidem, s. 93-94. 
W roku 1932 wyszło najlepsze opracowanie, precyzujące założenia głębokiej operacji. Nosiło tytuł Ewolucja sztuki operacyjnej. Twórcą tego fundamentalnego dzieła był właśnie Georgij Isserson. W swojej książce zakładał, że sowiecka doktryna powinna oprzeć się na „koncepcjach decydującej ofensywnej operacji”33. Podobnie jak Triandafiłłow, Isserson wychodził z założenia, że obrona przyszłego przeciwnika będzie miała głębokość wynoszącą od 60 do $100 \mathrm{~km}$. Z tego powodu przyszłe operacje ofensywne „będą musiały pokonać całą głębokość nowoczesnej operacyjnej głębi" ${ }^{34}$. Zagadnienie samej głębi w sztuce wojennej scharakteryzował jako „główną rzecz w ewolucji nowoczesnych operacji (...), która określa jej nową ogromną intensywność”35. Dlatego „nowoczesna operacja jest operacją w głębi i musi być wliczona w całą głębokość i musi pokonać ją całą"36. Inną kwestią było podzielenie wojska na eszelony zaproponowane przez Triandafiłowa. Isserson rozwinął i doprecyzował myśl swojego poprzednika, określając skład strategicznego eszelonu początku wojny. Podobnie jak Triandafiłłow proponował użycie trzech eszelonów $\mathrm{w}$ operacji. Pierwszy operacyjny eszelon miałby natychmiast przekroczyć granice i zaatakować grupującego się przeciwnika. Drugi, w którego skład wchodziłyby broń pancerna i piechota zmechanizowana, miał na celu rozwinięcie powodzenia eszelonu pierwszego lub, w przypadku ofensywnej taktyki nieprzyjaciela, skierowanie go w zagrożony rejon. Nie miał być on rezerwą, tylko grupą powodzenia przełamania. Rola rezerwy była zarezerwowana dla trzeciej grupy wojsk. Warto nadmienić, że głębokie rozwinięcie uniemożliwia uzyskanie zaskoczenia na wyższym szczeblu sztuki wojennej niż taktyczny.

Schemat 1. Głębokie rozwinięcie we współczesnej operacji ${ }^{37}$

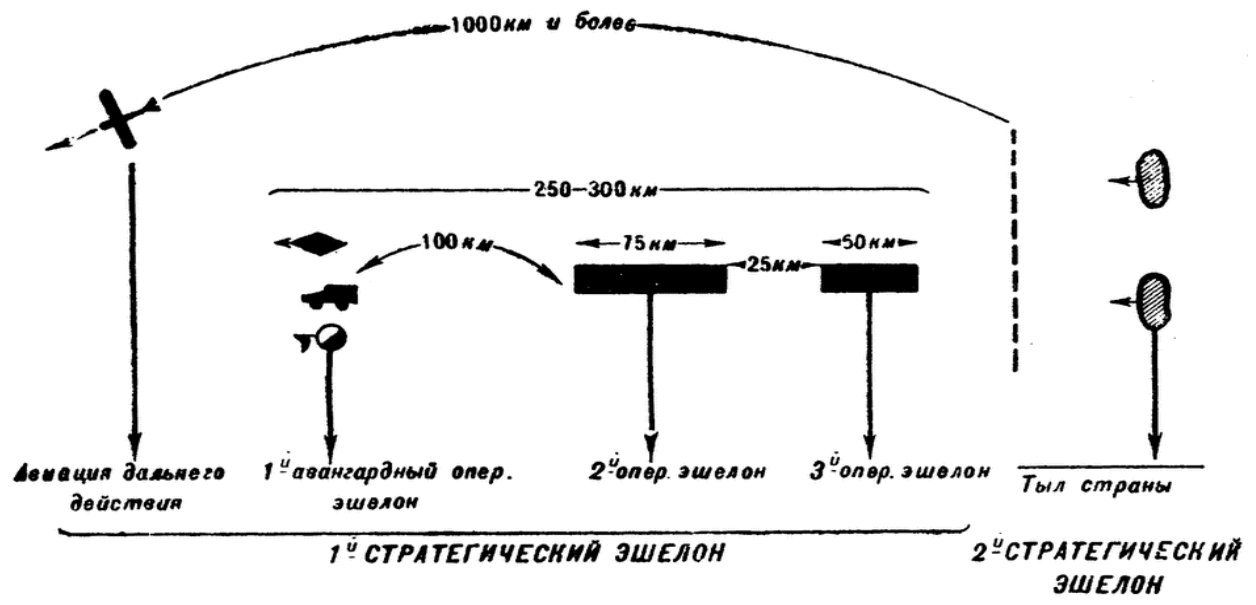

33 Cyt. za: ibidem, s. 105.

34 Cyt. za: ibidem, s. 106.

35 Cyt. za: ibidem.

36 Cyt. za: ibidem, s. 109.

37 Г. С. Иссерсон, ор. cit., s. 81. 
Prawdziwa przenikliwość Issersona ujawniła się w opisaniu operacji przełamującej, która miała rozpocząć się uderzeniem ogniowym artylerii i lotnictwa. W tym samym czasie rozpoczęłoby się natarcie eszelonu atakującego, w miejscu wyłomu operacyjnego. Gdy udało się uzyskać przełamanie, do akcji miał wejść eszelon przełamania w celu rozwinięcia sukcesu taktycznego w operacyjny. W jego skład miały wchodzić: grupy wojsk szybkich i zmotoryzowana piechota. Operacji przełamania miało być kilka na przestrzeni linii frontu, co miało umożliwić prowadzenie ofensywy na szerokim froncie, a w konsekwencji okrążenie i zniszczenie przeciwnika. Największym problemem operacji przełamującej było konsekwentne i jednoczesne dokonanie uderzenia na kilku odcinkach frontu. W przeciwieństwie do natarć z okresu pierwszej wojny światowej, w których ostrzał artyleryjski koncentrowano na pierwszej linii nieprzyjaciela, $\mathrm{w}$ „głębokim przełamaniu” związana ogniem miała być cała głębokość obrony. W ten sposób Isserson zakończył wielowiekową dyskusję na temat manewru po wewnętrznych i zewnętrznych liniach. Teraz liczyła się tylko głębia ${ }^{38}$.

Schemat 2. Operacja przełamująca ${ }^{39}$

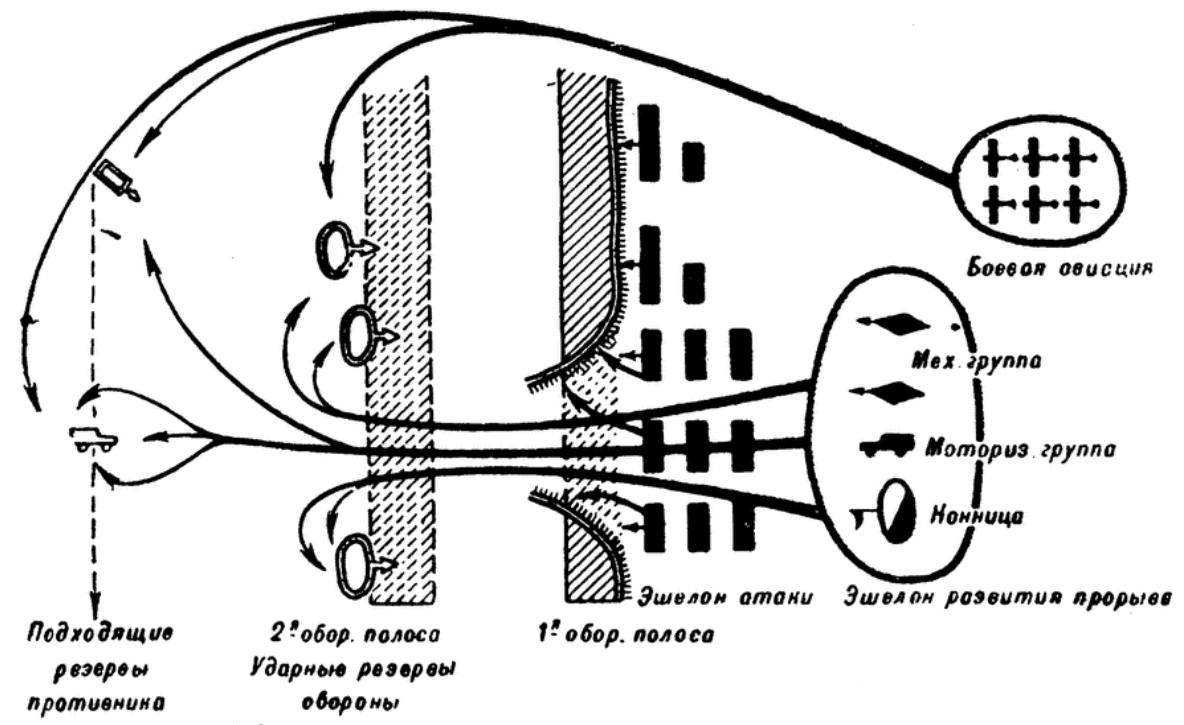

Ewolucja sztuki operacyjnej miała nakład 10000 egzemplarzy, pokaźny jak na tamte czasy i była najlepszym opracowaniem sztuki operacyjnej od książki Triandafiłłowa $^{40}$. Nie zaprzeczała tezom postawionym w Charakterze operacji współczesnych armii, ale rozwijała je.

38 R. W. Harrisom, Architect of Soviet..., s. 113-114.

39 Г. С. Иссерсон, op. cit., s. 85.

40 R. W. Harrisom, Architect of Soviet..., s. 115. 
Kolejną książką Issersona, wydaną w roku 1933, były Podstawy głębokich operacji. Ewolucja sztuki operacyjnej miała wiele godnych uwagi tez, ale nie była to instrukcja operacyjna z prawdziwego zdarzenia. Stąd w swojej książce Podstawy głębokich operacji Isserson podaje szczegółowe dane. Stworzył własną „armię uderzeniową”, w której skład miało wejść: 350 tysięcy żołnierzy, 1427 dział, 1457 czołgów i 1045 samolotów. W tym miejscu Isserson mylił się co do liczebności amii uderzeniowej. W okresie drugiej wojny światowej armie uderzeniowe miały siłę trzykrotnie mniejszą. O wiele lepszy model „armii uderzeniowej” dał Warfołomjew w swojej książce pod tytułem Armia uderzeniowa. Po prostu nie precyzował jej składu, koncentrując się na jej zadaniach i uzależniając jej skład od wielu czynników takich, jak teren operacji czy misja do wykonania ${ }^{41}$. W kwestii „armii uderzeniowej” Isserson wykazał się charakterystyczną dla sowieckich dowódców megalomaniąą . W opisie „bitwy spotkaniowej” nie powiodło mu się przewidzenie jej charakteru. Zaznaczył jednak, że jest to najbardziej nieobliczalny rodzaj starcia zbrojnego ${ }^{43}$. Za to w scharakteryzowaniu „bitwy przełamującej” rozstrzygnął wszystkie ważne kwestie. Pierwszą był moment wejścia w wyłom grupy manewrowej. Wymagał od dowódcy „operacji przełamującej” przede wszystkim koordynacji pomiędzy grupą przełamującą a grupą rozwinięcia powodzenia. Ta druga nie mogła wejść w wyłom ani za wcześnie, ani za późno (bardziej szkodliwe dla przebiegu operacji było odwleczone zastosowanie). W pierwszym przypadku zostałaby wciągnięta w walki na szczeblu taktycznym. Doprowadziłoby to do jej szybkiego osłabienia i mogło uniemożliwić wykorzystanie wyłomu do celów operacji. Przy za późnym wprowadzeniu w wyłom dawano nieprzyjacielowi możliwość do cofnięcia w głąb obrony, w konsekwencji czego operację przełamania należało rozpocząć od nowa ${ }^{44}$. Isserson zaproponował podział bitwy przełamującej na cztery etapy. Pierwszym było, trwające dzień lub dwa, przygotowanie lotnicze. Celem sił powietrznych było uderzenie na lotniska nieprzyjaciela, linie zaopatrzeniowe, rezerwy operacyjne i strategiczne. Drugim etapem było przełamanie taktycznej obrony nieprzyjaciela. W tym miejscu miały być wprowadzone rezerwy taktyczne w celu uniemożliwieniu cofnięcia się sił przeciwnika na drugą linię obrony. W kolejnym etapie wprowadzano rezerwy operacyjne i wykorzystywano pokonanie taktycznej strefy obrony nieprzyjaciela. W ostatniej fazie niszczono wojska przeciwnika i ugruntowywano wyłom ${ }^{45}$. Finalnym założeniem Issersona była koncepcja „następujących po sobie operacji”. Po dokonaniu analizy wybranych przykładów historycznych przedstawiał jak ryzykowne jest planowanie pokonania przeciwnika w jednej tylko operacji ${ }^{46}$.

41 Ibidem, s. 129.

42 Jednym z przykładów jest plan rozwinięcia MP-41, który zakładał zapotrzebowanie na sprzęt w Armii Czerwonej na poziomie 36879 czołgów, 10679 samochodów pancernych i 90847 ciągników i traktorów. Zob. M. Sołonin, 23 czerwca..., s. 41.

43 R. W. Harrisom, Architect of Soviet..., s. 129-138.

44 Ibidem, s. 142-143.

45 Ibidem, s. 144-145.

46 Ibidem, s. 147-148. 
Pomimo rozbudowanych założeń czysto teoretycznych, o przyjęciu doktryny głębokich operacji jako obowiązującej całą Armię Czerwoną możemy mówić dopiero od roku 1936. Wtedy wprowadzono Tymczasowy regulamin polowy Armii Czerwonej, w skrócie PU-36. W owym regulaminie widać wpływ koncepcji prezentowanych w niniejszej pracy. Przykładem jest chociażby artykuł 164. Czytamy w nim: „W wspólnych operacjach wszystkich oddziałów i służb, ofensywna operacja musi mieć na celu jednoczesne przytłoczenie całej głębokości nieprzyjacielskiej obrony" ${ }^{37}$. Regulamin z 1936 r. jest ostatnim przejawem zaangażowania w sowiecką myśl wojskową dowódców wywodzących się z tak zwanej „szkoły operacyjnej”. W kolejnych latach zostają oni wyeliminowani w trakcie Wielkiej Czystki.

Represje nie raz spadały na korpus oficerski Armii Czerwonej. W połowie lat 20. przeprowadzono czystkę wśród kadry dowódczej i pracowników politycznych, podejrzewanych o współpracę z opozycją trockistowską. W efekcie w listopadzie 1928 r. 72\% kadry dowódczej mogło wykazać się robotniczym lub chłopskim pochodzeniem. Od 1 listopada do 31 grudnia 1928 r. usunięto z wojska 4473 osoby z kadry dowódczej. Kolejne represje były związane z zabójstwem Kirowa. Od 1 grudnia 1934 r. do 20 stycznia jedynie w Moskiewskim Okręgu Wojskowym aresztowano 43 wojskowych. Zwolniono 131 osób z Akademii Wojskowo-Politycznej, po czym wielu aresztowano i stracono. Szczyt aresztowań przypadł na lata 1937-1938 ${ }^{48}$.

Tabela 1. Represje wobec wyższych oficerów sowieckich sił zbrojnych w latach 1935-1940 badania Pawła Piotra Wieczorkiewicza ${ }^{49}$

\begin{tabular}{|l|l|l|l|l|l|l|}
\hline Stopień & $\begin{array}{l}\text { Stan na } \\
31.12 .36\end{array}$ & Samobójcy & $\begin{array}{c}\text { Usunięci } \\
1936-39\end{array}$ & Aresztowania & Straceni & Zmarli \\
\hline Marszałek & 5 & - & 3 & 3 & 2 & 1 \\
\hline Komandarm 1 rangi & 4 & - & 5 & 5 & 5 & - \\
\hline Fłagman fłota 1 rangi & 2 & - & 2 & 2 & 2 & - \\
\hline Armkom 1 rangi & 1 & 1 & 1 & 1 & 1 & - \\
\hline Komandarm 2 rangi & 10 & - & 10 & 10 & 10 & - \\
\hline Armkom 2 rangi & 15 & 1 & 14 & 14 & 14 & - \\
\hline Armwojenjurist & 1 & - & 1 & 1 & - & 1 \\
\hline Komkor & 63 & 1 & 63 & 62 & 53 & 4 \\
\hline Korkom & 30 & - & 30 & 29 & 21 & 2 \\
\hline Komdiw & 201 & - & 171 & 164 & 116 & 12 \\
\hline Kombrig & 474 & 2 & 372 & 328 & 181 & 17 \\
\hline
\end{tabular}

47 PU-36, Rozdział 7, art. 164.

48 W. Bieszanow, Kadry decydują..., s. 91.

49 Dane do tabeli za: P. Wieczorkiewicz, op. cit., s. 892-893. 
Z 806 oficerów na wysokich stanowiskach dowódczych zlikwidowano 432. Nigdy i nigdzie nie przeprowadzono eksterminacji wyższej kadry dowódczej na taką skalę. Rozstrzelano osoby pełniące następujące funkcje: 3 zastępców narkoma obrony, narkoma floty wojennej, 16 dowódców wojsk okręgów, 25 ich zastępców i pomocników, 5 dowódców floty, 8 szefów akademii wojskowych, 25 szefów sztabów okręgowych, floty i ich zastępców, 33 dowódców korpusów, 76 dowódców dywizji, 40 dowódców brygad, 291 dowódców pułków, 2 zastępców szefa Zarząadu Politycznego RKKA i szefa Zarządu Politycznego WMF ${ }^{50}$.

Armia została dosłownie pozbawiona „głowy”. Zabito całe dowództwo marynarki wojennej, wszystkich dowódców okręgów wojskowych i ich zastępców awansowanych od 1924 roku. Taki sam los spotkał cały Sztab Generalny oraz poszczególne zarządy. Z oficerów, którzy w dużym stopniu wzbogacili sowiecką myśl wojskową rozstrzelani zostali: Warfołomjew (1939), Wierchowski (1938), Mowczin (1938) i Sweczin (1938). Isserson miał więcej „szczęścia”. Został wypuszczony na wolność po wieloletnim więzieniu ${ }^{51}$.

Skutki Wielkiej Czystki są bardzo trudne do oceny. Utrudnia ją brak monografii porównującej skalę problemów w rozbudowie Wehrmachtu czy US Army. Już od dłuższego okresu Armia Czerwona była w stadium dynamicznego rozwoju, co obrazują tabela 2 i 3. Gwałtowny wzrost liczebności wpływał na obniżenie fachowości korpusu oficerskiego.

Tabela 2. Plany mobilizacyjne Armii Czerwonej w latach 1930-1934 ${ }^{52}$

\begin{tabular}{|l|l|l|l|l|l|}
\hline & $\begin{array}{l}\text { Plan } \\
\text { mobilizacyjny } \\
\text { nr 8 (1929) }\end{array}$ & $\begin{array}{l}\text { Plan } \\
\text { mobilizacyjny } \\
\text { nr 10 (1930) }\end{array}$ & $\begin{array}{l}\text { Plan } \\
\text { mobilizacyjny } \\
\text { nr 11 (1932) }\end{array}$ & $\begin{array}{l}\text { Plan } \\
\text { mobilizacyjny } \\
\text { nr 15 (maj 1933) }\end{array}$ & $\begin{array}{l}\text { Plan } \\
\text { mobilizacyjny } \\
1934\end{array}$ \\
\hline $\begin{array}{l}\text { Liczebność } \\
\text { sił zbrojnych }\end{array}$ & 2977629 & 3175324 & 3526250 & 4710500 & 4800000 \\
\hline
\end{tabular}

Tabela 3. Sowieckie siły zbrojne w czasie pokoju w latach 1930-193953

\begin{tabular}{|l|l|}
\hline Data & Liczebność sił zbrojnych \\
\hline 1.01 .1930 & 631616 \\
\hline 1.01 .1931 & 629783 \\
\hline 15.01 .1932 & 775519 \\
\hline 1.03 .1933 & 899912 \\
\hline 1.01 .1934 & 1033570 \\
\hline 1.01 .1935 & 1085173 \\
\hline
\end{tabular}

50 W. Bieszanow, Kadry decydują..., s. 92.

51 R. W. Harrisom, Architect of Soviet..., s. 223-224.

52 Dane do tabeli za: О. Кен, op. cit., s. 470-471.

53 Dane do tabeli za: B. Musiał, op. cit., s. 238. 


\begin{tabular}{|l|l|}
\hline Data & Liczebność sił zbrojnych \\
\hline 1.01 .1936 & 1219325 \\
\hline 1.01 .1937 & 1645983 \\
\hline $1.01 .1938^{54}$ & 1582057 \\
\hline 24.02 .1939 & 1931962 \\
\hline
\end{tabular}

Już w dwa lata po rozpoczęciu gwałtownego zwiększenia liczebności, w roku 1931, Armia Czerwona potrzebowała 15513 dodatkowych oficerów: 8046 do obsadzenia stanowisk w formowanych jednostkach, 2474 rekompensowało ubytki naturalne, $3103 \mathrm{w}$ celu usunięcia niedoborów $\mathrm{z}$ lat poprzednich i 1890 przeniesionych z wojska do innych obowiązków. Armia Czerwona liczyła, że szkoły wojskowe wykształcą 6850 oficerów, 4030 rezerwistom planowano zaproponowanie przedłużenia służby o kolejny rok i dodatkowo planowano powołać 440 rezerwistów. $\mathrm{Na}$ stanowisko dowódców kompanii chciano skierować 800 sierżantów. Dzięki tym wszystkim zabiegom armia otrzymałaby 12120 oficerów, co ograniczałoby niedobór do „jedynie” 3393 oficerów ${ }^{55}$. Przy czym braki były spowodowane głównie stopniową rozbudową Armii Czerwonej. W trakcie Wielkiej Czystki liczba oficerów w armii wzrastała, z 162 tysięcy w czerwcu 1937 do 179 tysięcy w końcu $1938 \mathrm{roku}^{56}$.

Dziwne było zachowanie Komisariatu Obrony w omawianym okresie. Zamiast ograniczyć rozbudowę armii ze względu na niedobór oficerów, jak zrobiono to chociażby w III Rzeszy, cały czas rozwijano Armię Czerwoną. Co więcej, nie robiono nic, by uatrakcyjnić zawód oficera. W roku 1935 zarabiali oni mniej niż brygadziści. Doprowadziło to do stanu niekończącego się zapotrzebowania na oficerów ${ }^{57}$.

Tabela 4. Wzrost liczby oficerów w służbie czynnej według rodzajów wojsk w okresie $1934-1939^{58}$

\begin{tabular}{|l|l|}
\hline Piechota & $281 \%^{59}$ \\
\hline Kawaleria & $166 \%$ \\
\hline Broń pancerna & $254 \%$ \\
\hline Artyleria & $224,5 \%$ \\
\hline Lotnictwo ogółem & $248 \%$ \\
\hline Piloci & $284 \%$ \\
\hline Technicy lotniczy & $901 \%$ \\
\hline
\end{tabular}

54 Lata 1938-1939 nie uwzględniają liczebności floty.

55 R. R. Reese, Czerwoni Dowódcy..., s. 123-124.

56 R. R. Reese, The Soviet Military Experience..., s. 87.

57 R. R. Reese, Czerwoni Dowódcy..., s. 124.

58 Tabela za: ibidem, s. 125.

$59 \mathrm{Za} 100 \%$ przyjęto stan na rok 1934. 
Tabela 5. Oficerowie przeniesieni z awansem i bez awansu, 1933-1938 ${ }^{60}$

\begin{tabular}{|l|l|l|l|}
\hline Rok & Przeniesieni $z$ awansem & Przeniesieni bez awansu & Przeniesieni ogółem \\
\hline 1933 & 28363 & & \\
\hline 1934 & 22000 & 21000 & 49363 \\
\hline 1935 & 22000 & 16000 & 38000 \\
\hline 1936 & 29000 & 29000 & 51000 \\
\hline 1937 & 26000 & 40000 & 69000 \\
\hline $1938^{61}$ & 59000 & 27000 & 53000 \\
\hline
\end{tabular}

Analizując dane z tabel 4 i 5, dochodzę do następujących wniosków. Po pierwsze, tak olbrzymi wzrost liczby czynnej kadry oficerskiej nie mógł odbyć się bez uszczerbku jej fachowości. Wraz z eksterminacją najlepszych teoretyków lat 20. i 30., w mojej ocenie likwidowano bardziej kreatywną części korpusu oficerskiego i pozostawiono spolegliwą. Po drugie, dwukrotny wzrost przeniesień między 1937 a 1938 r. śmiało można nazwać postępującym bałaganem w Armii Czerwonej, potęgowanym przez rosnący niedobór oficerów. Po trzecie, każda rozbudowywana armia bez należycie wykształconego i doświadczonego korpusu oficerskiego, będzie miała trudności z koncentracją przed jakąkolwiek operacją wojskową. Dodając do tego liczebność Armii Czerwonej, rozważniejsze byłoby przyjęcie postawy obronnej w początkowym okresie wojny. Alternatywą było jedynie złudzenie, że uda się zakończyć strategiczne rozmieszczenie przed przeciwnikiem, który w momencie zorientowania się, że na jego granicy koncentruje się Armia Czerwona, byłby wstanie zakończyć koncentrację szybciej i wyprowadzić wyprzedzające uderzenie.

Ani w planach wojny przeciw III Rzeszy, ani na posiedzeniu Głównej Rady Wojennej i wyższej kadry dowódczej Armii Czerwonej w grudniu 1940 r. nie ma żadnej wzmianki o działaniach obronnych na szczeblu wyższym niż taktyczny.

Grudniowe posiedzenie jest ostatnim spotkaniem wyższej kadry dowódczej Armii Czerwonej przed niemieckim atakiem w czerwcu 1941 roku. W szczególności interesujące były dwa referaty: generała-armii G. K. Żukowa, Charakter operacji zaczepnych ${ }^{62}$ i generała-pułkownika D. G. Pawłowa, Rola wojsk zmechanizowanych we współczesnej wojnie $e^{63}$. Pierwszy z wymienionych referatów nie wprowadza w gruncie rzeczy nic nowego. Był jedynie potwierdzeniem, że tezy Triandafiłłowa i Issersona zostały przyjęte i dostosowane do rozwiązań taktycznych i operacyjnych. O wiele ciekawszy i reprezentujący nowe poglądy jest referat generała Pawłowa i dyskusja z nim związana.

W swoim wystąpieniu Pawłow próbuje rozstrzygnąć dwie kwestie: kiedy ma wejść w wyłom „grupa manewrowa" i kto ma o tym zadecydować. Na pierwsze z posta-

60 Tabela za: R. R. Reese, Czerwoni Dowódcy..., s. 134.

61 Tylko pierwsze 10 miesięcy.

62 Armia Czerwona w przededniu..., s. 191-225.

63 Armia Czerwona w latach..., s. 72-100. 
wionych pytań Pawłow odpowiada: „Dlatego uważam, że lepiej korpus pancerny wprowadzić jest [w przełamanie] wcześniej, niż oczekiwać póki korpusy piechoty przerwą i drugi pas obronny, stracą czas i dadzą przeciwnikowi możliwość w chwili przełamania w ciągu nocy podciągnąć dowolną liczbę wojsk i środki przeciwpancerne. (...) Na typ etapie wszystkie dążenia dowódców korpusu pancernego sprowadzają się do tego, żeby jak można najszybciej zorganizować i szybko przeprowadzić ugrupowanie bojowe przez strefę oporu przeciwnika” ${ }^{64}$. Zaś na drugie: „Uważam, że czas i moment wprowadzenia w przełamanie jest zobowiązany określić sam dowódca korpusu pancernego"65. Oba stwierdzenia generała Pawłowa są błędne i dowodzą jego małego zrozumienia sztuki operacyjnej. Na szczeblu taktycznym istnieje ryzyko wprowadzenia rezerw (a „grupa manewrowa” niewątpliwie jest rezerwą) za wcześnie i tego Pawłow chciał uniknąć. W sztuce operacyjnej ryzyko przedstawia się odwrotne. Większe szkody powoduje za późne wprowadzenie odwodów. Jedynym podejmującym decyzje o czasie i miejscu wprowadzenia grupy powodzenia przełamania jest tylko i wyłącznie dowódca całej armii lub frontu, w zależności od skali operacji. On jako jedyny posiada obraz całej sytuacji, której są pozbawieni oficerowie na niższych szczeblach dowodzenia.

Referat generała Pawłowa wywołał bardzo żywą dyskusję. Godne uwagi były zwłaszcza wystąpienia: generała-majora M. G. Chackilewicza, dowódcy 6 Korpusu Zmechanizowanego i generała-majora B. G. Wierszinina, generała-inspektora wojsk samochodowych i pancernych. Chackilewicz rozstrzyga jednoznacznie problem, kto ma decydować o wejściu „grupy manewrowej” w wyłom: „Uważam, że jeżeli korpus pancerny jest środkiem dowództwa armii i frontu, to powinien być odpowiedzialny pełnomocny przedstawiciel armii lub frontu, który będąc zorientowanym w całej sytuacji na froncie powinien na miejscu od razu powiedzieć: Czas nadszedt, wprowadźcie korpus w przełamanie. (...) Uważam, że tę sprawę rozwiązuje dowódca armii" 66 . Był to jak najbardziej prawidłowy wniosek. Drugi referent, generał Wierszinin, skoncentrował się na kwestiach technicznych wejścia „grupy manewrowej” w wyłom: „Moment wprowadzenia korpusu zmechanizowanego zależy (...) od zadania korpusu zmechanizowanego - czy powinien on wykonać zadanie taktycznego okrążenia, czy powinien on iść w głębokie przełamanie"67. Powyższe zdanie dowodzi zrozumienia podstawowych kanonów sztuki wojennej przez generała Wierszynina. Starał się dać jak najbardziej ogólną charakterystykę kwestii wprowadzenia korpusu zmechanizowanego w wyłom, uwzględniając niezbędną swobodę dla dowódcy "grupy manewrowej". Innym, w mojej ocenie, prawidłowym postulatem Wierszynina jest wejście w przełamanie korpusu zmechanizowanego rzutami: „Niekiedy jest potrzeba wprowadzenia korpusu w bardzo wąski pas 8-10 kilometrów, przed [którym] nie należy się zatrzymywać. Trzeba będzie tylko w odpowiedni sposób

64 Ibidem, s. 99.

65 Ibidem.

66 Ibidem, s. 108.

67 Ibidem, s. 128. 
urzutować ugrupowanie bojowe związku zmechanizowanego i wprowadzać [go] nie w jednym rzucie, a w dwóch, albo w trzech"68.

Od drugiej połowy roku 1940 Związek Sowiecki planował agresję na swojego zachodniego sąsiada. Nie był to atak skierowany tylko na III Rzeszę, ale również na Finlandię. W dostępnych obecnie dokumentach brak jest planów ataku na Rumunię. Brak agresywnych zamiarów Armii Czerwonej względem tego państwa w tym okresie potwierdza bierność Frontu Południowego w pierwszych dniach po 22 czerwca 1941 roku.

Pierwszym dokumentem świadczącym o tym jest raport ludowego komisarza obrony ZSRS i szefa Sztabu Generalnego Armii Czerwonej do KC WKP(b) na ręce Józefa Stalina i Wiaczesława Mołotowa, „O zasadach strategicznego rozwinięcia Sił Zbrojnych ZSRS na Zachodzie i na Wschodzie”, podpisanego najpóźniej 19 sierpnia $1940 \mathrm{roku}^{69}$. Dowództwo Armii Czerwonej zamierzało główne uderzenie wyprowadzić na Zachód: „Podstawowym zadaniem naszych wojsk jest doprowadzić do klęski sił niemieckich koncentrujących się w Prusach Wschodnich i w rejonie Warszawy; uderzeniem wspierającym zadać klęskę zgrupowaniu nieprzyjaciela Iwangorod [Dęblin] Lublin, Hrubieszów, Tomaszów, Sandomierz"70. W kwestii Finlandii warte odnotowania jest zdanie: „Przystąpienie do wojny samej Finlandii jest mało prawdopodobne"71.

18 września tego samego roku ukazały się dwa dokumenty podpisane przez Siemiona Timoszenkę i Kiriłł Mierieckowa (wykonawca: Aleksander Wasilewski). Pierwszy z nich to raport numer 103202/ow ludowego komisarza obrony ZSRS i szefa Sztabu Generalnego Armii Czerwonej dla KC WKP(b) do J. Stalina i W. Mołotowa „O zasadach rozwinięcia strategicznego sił zbrojnych ZSRS na Zachodzie i na Wschodzie"72. Zarówno pod względem nazwy, jak i treści, dokument jest powtórzeniem planu z 19 sierpnia. Kierunek fiński pozostawał drugorzędny.

O wiele ciekawszy jest drugi dokument $\mathrm{z}$ tego dnia. Jest to raport numer 103203 „Wnioski dotyczące rozwinięcia sił Armii Czerwonej na wypadek wojny z Finlandią" W tym dokumencie wnioski na temat Finlandii są odmienne niż w dwóch przeze mnie wymienionych wcześniej: „uderzenie głównych sił Frontu Północno-Zachodniego przez Savonlinnę na Sankt Michel (Mikkeli) i przez Lappeenrantę na Heinolę, z ominięciem umocnień utworzonych na kierunku helsińskim i równoczesne

68 Ibidem, s. 130.

69 Записка наркома оъороны СССР и начальника Генштаба Красной Армии в ЦК ВКП(б) И. В. Сталина и В. М. Молотову об основах стратегического развертывания Вооруженных Сил СССР на Западе и на Востоке на 1940 и 1941 годы, [w:] Россия - ХХ век..., t. 1, s. 181-193.

70 Ibidem.

71 Ibidem.

72 Записка наркома оъороны СССР и начальника Генштаба Красной Армии в ЦК ВКП(б) И. В. Сталина и В. М. Молотову об основах стратегического развертывания Вооруженных Сил СССР на Западе и на Востоке на 1940 и 1941 годы, [w:] ibidem, s. 236-253.

73 Записка наркома оъороны СССР и начальника Генштаба Красной Армии в ЦК ВКП(б) И. В. Сталина и В. М. Молотову соображениях по развертыванию вооруженных сил Красной Армии на случай войны с Финляндией, [w:] ibidem, s. 253-260. 
uderzenie z Wyborga przez Sippolę na Helsinki, wtargnąć do Finlandii Środkowej, rozgromić tu zasadnicze siły armii fińskiej i opanować centralną część Finlandii. Uderzenie to powiązać z uderzeniem na Helsinki od strony półwyspu Hanko i z działaniami $\mathrm{FB}^{74} \mathrm{w}$ Zatoce Fińskiej"75. Z porównania obu dokumentów wynika, że Związek Sowiecki przygotowywał się do drugiej wojny zimowej, której rozpoczęcie miało nastąpić jeszcze w 1940 roku.

W przygotowaniu ataku na III Rzeszę, oprócz materiałów wymienionych przeze mnie w poprzednim akapicie, $\mathrm{w}$ chwili obecnej dostępne są następujące dokumenty:

- Raport ludowego komisarza obrony ZSRS i szefa Sztabu Generalnego Armii Czerwonej dla KC WKP(b) oraz J. Stalina i W. Mołotowa nr 103313 (dokument zaczyna się słowami „Przedstawiam Wam do akceptacji kluczowe wnioski z Waszych zaleceń z 5 października 1940 roku dotyczących planów rozwinięcia strategicznego Sił Zbrojnych ZSRS na 1941 rok", w związku z czym zazwyczaj jest określany jako „poprawiony plan rozwinięcia strategicznego” ${ }^{76}$.

- Raport szefa sztabu Kijowskiego Specjalnego Okręgu Wojskowego odnośnie do decyzji Rady Wojennej Frontu Południowo-Zachodniego, dotyczącej planu rozwinięcia operacyjnego na 1940 rok, b. n., nie później niż grudzień $1940 \mathrm{roku}^{77}$.

- Raport ludowego komisarza obrony ZSRS i szefa Sztabu Generalnego Armii Czerwonej dla KC WKP(b) oraz J. Stalina i W. Mołotowa „Poprawione założenia rozwinięcia strategicznego Sił Zbrojnych ZSRS na zachodzie i na wschodzie", b. n., z 11 marca 1941 roku $^{78}$.

- Dyrektywa ludowego komisarza Obrony ZSRS i szefa Sztabu Generalnego Armii Czerwonej dla dowództwa Zachodniego Okręgu Wojskowego w sprawie opracowania planu rozwinięcia operacyjnego oddziałów okręgu, b. n., kwiecień $1941 \mathrm{roku}^{79}$.

- Opinie na temat rozwinięcia strategicznego Sił Zbrojnych Związku Sowieckiego w przypadku wojny z Niemcami i ich sojusznikami, b. n., nie wcześniej niż 15 maja 1941 roku $^{80}$.

Nie jest moim celem w tym miejscu analiza wszystkich tych dokumentów, a jedynie pokazanie ogólnego kierunku uderzenia na Niemcy. Można przyjąć jako pewnik,

74 Floty Bałtyckiej.

75 Ibidem.

76 Записка наркома оъороны СССР и начальника Генштаба Красной Армии в ЦК ВКП(б) И. В. Сталина и В. М. Молотову, [w:] ibidem, s. 288-290.

77 Записка пачальника штаба КОВО по решению Военого Совета Юго-Западного Фронта по планы развертывания на 1940, [w:] ibidem, s. 484-497.

78 План Генштаба Красной Армии стратегическое развертывание вооруженных сил Советский Союз на западе и востоке, [w:] ibidem, s. 741-745.

79 Директива наркома обороны СССР и начальника Генштаба Красной Армии командующиму войсками ЗАНОВО генерал-полковник Д. Г. Павлову, [w:] Россия - ХХ век..., t. 2, s. 133-139.

80 Записка наркома оъороны СССР и начальника Генштаба Красной Армии Председателю СНК СССР И. В. Сталина стратегической точки зрения план развертывания Вооруженных Сил СССР на случай войны с Германией и ее союзниками, [w:] ibidem, s. 215-220. 
że prace nad planem ataku na III Rzeszę trwały od sierpnia 1940 r. i od tego czasu plany były tylko nieznacznie zmieniane:

1. „Współdziałając z 4. Armią Frontu Zachodniego, zdecydowanie rozgromić lubelsko-sandomierskie zgrupowanie nieprzyjaciela i wyjść na Wisłę. Dalsze uderzenie w kierunku na Kielce-Piotrków oraz Kraków, opanować rejon Kielce-Piotrkówna i wyjść na rz. Pilica i górny bieg rz. Odra" ${ }^{81}$.

2. „Początkowe zadanie strategiczne - rozgromić, współdziałając z 4. Armią Frontu Zachodniego, siły zbrojne Niemiec w rejonie Lublin, Kielce, Radom oraz Rzeszów, Jasło, Kraków i wyjść w 30 dniu operacji na front rz. Pilica, Piotrków, Opole, Prudnik, odcinając Niemców od południowych sojuszników"82.

3. „Głównymi siłami Frontu Południowo-Zachodniego, współdziałając z lewym skrzydłem Frontu Zachodniego, przeprowadzić uderzenie i zdecydowanie rozgromić lubelsko-radomsko-sandomiersko-krakowskie zgrupowanie nieprzyjaciela, sforsować Wisłę, opanować Kraków i Warszawę oraz wyjść na linię Warszawa, Łódź, Kluczbork, Opole"83.

4. „Wraz z rozpoczęciem przez armie Frontu Południowo-Zachodniego natarcia uderzyć lewym skrzydłem frontu na ogólnym kierunku na Siedlce, Radom, wspomagając Front Południowo-Zachodni w rozgromieniu lubelsko-radomskiego zgrupowania nieprzyjaciela. Początkowe zadanie frontu - opanować rejon Łukowa oraz przeprawy przez Wisłę; następnie skierować działania na Radom w celu całkowitego okrążenia lubelskiego zgrupowania nieprzyjaciela, współdziałając z Frontem Południowo-Zachodnim" ${ }^{\text {"2 }}$.

5. „Główne uderzenie siłami Frontu Południowo-Zachodniego w kierunku Kraków, Katowice, i odcięcie Niemiec od ich południowych sojuszników; wspomagające uderzenie lewym skrzydłem Frontu Zachodniego w kierunku Siedlec, Dęblina, w celu związania zgrupowania warszawskiego i współdziałania z Frontem Południowo-Zachodnim w rozgromieniu lubelskiego zgrupowania nieprzyjaciela" 85 .

Są to wybrane podpunkty z pięciu różnych dokumentów. Prace nad nimi prowadziło trzech szefów sztabu: Szaposznikow, Mierieckow i Żukow. Podkreślone fragmenty wskazują na zgodność założeń tych planów i to w detalach. Wybór wariantu „południowego" został ostatecznie zatwierdzony po grach wojennych na początku 1941

81 Записка наркома оъороны СССР и начальника Генштаба Красной Армии в ЦК ВКП(б) И. В. Сталина и В. М. Молотову, [w:] ibidem, s. 288-290.

82 Записка пачальника штаба КОВО по решению Военого Совета Юго-Западного Фронта по планы развертывания на 1940, [w:] ibidem, s. 484-497.

83 План Генштаба Красной Армии стратегическое развертывание вооруженных сил Советский Союз на западе и востоке, [w:] ibidem, s. 741-745.

84 Директива наркома обороны СССР и начальника Генштаба Красной Армии командующиму войсками ЗАНОВО генерал-полковник Д. Г. Павлову, [w:] ibidem, s. 133-139.

85 Записка наркома оъороны СССР и начальника Генштаба Красной Армии Председателю СНК СССР И. В. Сталина стратегической точки зрения план развертывания Вооруженных Сил СССР на случай войны с Германией и ее союзниками, [w:] ibidem, s. 215-220. 
roku. Co ciekawe, chronologię gry określano nie mianem „w pierwszym, drugim... dniu mobilizacji", ale od 8 do 20 sierpnia $^{86}$.

Najważniejszym dokumentem $\mathrm{z}$ wyżej wymienionych są „Opinie w sprawie planu rozwinięcia strategicznego Sił Zbrojnych Związku Sowieckiego na wypadek wojny z Niemcami i ich sojusznikami”. 24 maja w gabinecie Stalina odbyło się zebranie najważniejszych władz wojskowych i politycznych. Udział w nim wzięli:

- ludowy komisarz spraw zagranicznych Mołotow,

- ludowy komisarz obrony Timoszenko,

- szef Sztabu Generalnego Żukow i jego pierwszy zastępca, szef Zarządu Operacyjnego Watutin,

- szef Głównego Zarządu Sił Powietrznych Armii Czerwonej Żygariew,

- dowódcy wojsk pięciu zachodnich okręgów wojskowych (leningradzkiego, nadbałtyckiego, zachodniego, kijowskiego i odeskiego), członkowie rad wojennych (komisarze) i dowódcy sił powietrznych owych okręgów ${ }^{87}$.

Przez kilka miesięcy przed 24 maja nie było innych zebrań w równie wysoko postawionym gronie. Takiego spotkania nie ma też później, aż do momentu rozpoczęcia wojny ${ }^{88}$. W majowych „Wnioskach” ważne są dwa fragmenty. Pierwszym jest cytowany przez mnie dokument numer 5. Drugi fragment dotyczy niemieckich przygotowań: „Biorąc pod uwagę, że Niemcy mają obecnie armię zmobilizowaną, $\mathrm{z}$ rozwiniętymi tyłami, mogą wyprzedzić nas $\mathrm{w}$ rozwinięciu wojsk i zadać niespodziewany cios. Ażeby temu zapobiec [rozgromić armię niemiecką], uważamy za konieczne, by w żadnym razie nie oddawać niemieckiemu dowództwu inicjatywy, wyprzedzić przeciwnika w rozwijaniu i zaatakować armię niemiecką, gdy będzie ona znajdować się w stadium rozwijania i nie zdąży jeszcze zorganizować frontu i współdziałania rodzajów wojsk"89. Z powyższego fragmentu jednoznacznie wynika, że kierownictwo Związku Sowieckiego zdawało sobie sprawę z przygotowań niemieckich i zamierzało oddać wyprzedzający cios, co jest zgodne z kanonami sztuki wojennej. Nie wolno dobrowolnie oddawać inicjatywy przeciwnikowi. Czas pokazał, że Niemcy szybciej zakończyły koncentrację i zaatakowały jako pierwsze.

Dodatkowo rozmieszczenie z majowych opinii potwierdza ostatni znany przedwojenny dokument „O rozwinięciu Sił Zbrojnych ZSRS na wypadek wojny na Zachodzie" ${ }^{\prime 90}$, z 13 czerwca 1941 roku.

86 M. Sołonin, Nic dobrego..., s. 36.

87 На приеме у Сталина..., s. 334.

88 Ibidem, s. 323-337.

89 M. Sołonin, 23 czerwca..., s. 504-505.

90 Справка о развертывании вооруженных сил СССР на случай войны на западе, [w:] Россия - ХХ век..., t. 2, s. 358-361. 
Tabela 6. Porównanie faktycznego rozwinięcia z czerwca 1941 z majowymi opiniami i planem rozwinięcia z 13 czerwca $^{91}$

\begin{tabular}{|l|l|l|l|}
\hline & Opinie" & $\begin{array}{l}\text { "Rozwinięcie } \\
\text { Sił Zbrojnych" } \\
\text { z maja } 1941 \text { czerwca } \\
1941\end{array}$ & $\begin{array}{l}\text { Faktyczne ześrodkowanie } 22 \\
\text { czerwca 1941 }\end{array}$ \\
\hline Front Północny & 3 armie & 3 armie & armie: 14., 7., 23. \\
\hline Front Północno-Zachodni & 3 armie & 3 armie & armie: 27., 8., 11. \\
\hline Front Zachodni & 4 armie & 4 armie & armie: 3., 10., 4., 13. \\
\hline Front Południowo-Zachodni & 8 armii & 8 armii & armie: 5., 6., 26., 12., 18., 9. \\
\hline Odwód Naczelnego Dowództwa & 5 armii & 5 armii & armie: 22., 20., 21., 19., 16., 24., 28. \\
\hline
\end{tabular}

Rozmieszczenie najsilniejszych korpusów zmechanizowanych potwierdza zarówno fakt przygotowania się do ataku, jak również zdradza główne kierunki natarcia. 6. Korpus Zmechanizowany generała majora M. G. Chackilewicza wchodził w skład Zachodniego Specjalnego Okręgu Wojskowego. Rozlokowany w „występie białostockim”92, liczył 1131 czołgów, w tym 452 czołgi KW i T-34. W tym samym występie rozlokowano kolejne trzy korpusy zmechanizowane ${ }^{93}$. Został dobrze zamaskowany w lasach na wschód od Białegostoku i nie został wykryty przez niemieckie lotnictwo zwiadowcze ${ }^{94}$.

4. Korpus Zmechanizowany A. A. Własowa wchodził w skład kijowskiego specjalnego okręgu wojskowego. Jego rejonem dyslokacji był Lwów ${ }^{95}$. W skład wchodziło 979 pojazdów, z czego 414 to KW i T-34 ${ }^{96}$. Co ciekawe, już 20 czerwca $1941 \mathrm{r}$. ogłoszono alarm bojowy w 8. Dywizji Pancernej i 81. Dywizji Zmechanizowanej, a 22 czerwca tego roku o godzinie 2.00 ogłoszono alarm w 32. Dywizji Pancernej ${ }^{97}$.

8. Korpus Zmechanizowany generała D. I. Riabyszewa stacjonował na południe od 4 KZ w rejonie Drohobycz-Stryj ${ }^{98}$. Liczył 899 czołgów, z czego 171 KW i T-34 ${ }^{99}$. Już 19 czerwca dowódca korpusu wydał rozkaz wymarszu do rejonu ześrodkowania, a 22 czerwca o godzinie 10.00 korpus otrzymał rozkaz, po którym ogłoszono alarm, i do końca dnia dotarł on do granicznej rzeki San ${ }^{100}$. Poza tym w drugim rzucie strategicznym ${ }^{101} \mathrm{w}$ okolicach Orszy na Białorusi i Szepietówki na Ukrainie formowały się 5. KZ liczący 1070 czołgów oraz 7 . KZ w liczbie 959 maszyn ${ }^{102}$.

91 Tabela za: M. Sołonin, 23 czerwca..., s. 204.

92 M. Sołonin, 22 czerwca..., s. 100.

93 Ibidem, s. 46.

94 Ibidem, s. 101.

95 Ibidem, s. 269.

96 Ibidem, s. 240.

97 Ibidem, s. 269-270.

98 Ibidem, s. 270.

99 Ibidem, s. 240.

100 Ibidem, s. 270.

101 Przed II wojną światową w Związku Radzieckim było 16 okręgów wojskowych, 8 przygranicznych i tyle samo wewnętrznych. 13 maja 1941 r. sztaby 7 wewnętrznych (wszystkich oprócz moskiewskiego) przekształcono w sztaby armii, miesiąc później zaś rozpoczęto przemieszczenie tych armii w kierunku granicy zachodniej. Był to tzw. drugi rzut strategiczny. Zob. W. Suworow, Lodołamacz..., s. 219.

102 M. Sołonin, 22 czerwca..., s. 46. 
1. Korpus Zmechanizowany generała Czerniawskiego stacjonował w okolicach Pskowa ${ }^{103}$. Już 17 czerwca podniesiono alarm w 1. Dywizji Pancernej ${ }^{104}$. Była to jednostka elitarna. W jej skład weszły brygady czołgów wyróżniające się w czasie „wojny zimowej”. Ostatnie jednostki wchodzące w skład tej jednostki opuściły stację w Bieriezkach, na północnym zachodzie od Pskowa, w nocy z 18 na 19 czerwca $^{105}$. 22 czerwca czołowe transporty dotarły do Ałakurtti, $260 \mathrm{~km}$ od Murmańska i 60 $\mathrm{km}$ od granicy fińskiej. Ponadto rozmieszczenie 5. i 7. KZ pokazuje, że urzutowanie strategiczne Issersona zostało zrealizowane i „podzielono” wojsko na trzy grupy. Wyjątek stanowił 1. KZ, którego zadaniem było „przepołowienie” Finlandii w najwęższym miejscu.

Podsumowując, podstawy sowieckiej doktryny wojennej zostały opracowane na przełomie lat 20. i 30. XX wieku, głównie dzięki dwóm osobom: Władimirowi Triandafiłłowowi i Georgijowi Issersonowi. Zwłaszcza zasługi tego drugiego są nieocenione, lecz stosunkowo słabo znane. Pomimo destrukcyjnej roli, jaką w Armii Czerwonej odegrała Wielka Czystka, obowiązywała ona nadal w latach 1940-1941, czego dowodem jest po pierwsze posiedzenie Głównej Rady Wojennej w grudniu roku 1940. Zarówno wojna domowa w Hiszpanii, jak i seria sowieckich agresji na ościenne państwa nie wpłynęły na sowiecką sztukę operacyjną. Po drugie, znane nam dziś fragmenty planów wojny przeciw III Rzeszy również potwierdzają trwałość poglądów tych dwóch oficerów.

\section{Soviet operational art in the years 1940-1941}

The article presents the evolution of Soviet operational art since the 1920s. The author intends to provide an answer to several questions: What was the state of research on Soviet operational art before the Great Purge? What was the extent of repression? Were the intellectual achievements of the executed officers abandoned? The article also raises the subject of Soviet operational and strategic planning on the eve of the Third Reich's invasion on the USSR.

Particular focus is given to the session of the Main Military Council and senior commanding officers of the Red Army in December 1940, as several lectures delivered on this occasion were crucial to the settlement of contentious issues regarding Soviet operational art. In his work, the author refers inter alia to publications of Soviet officers from the period and contemporary American historians.

Translated by Jakub Perliński

\section{Советское оперативное искусство 1940-1941 гг.}

В статье речь идет об эволюции советского оперативного искусства в период 20-х гг. ХХ века. Автор намеревался ответить на несколько вопросов: каково было состояние исследований советского оперативного искусства до «Большой чистки», каков был масштаб репрессий и было ли вместе с устранением офицеров заброшено их интеллектуальное

103 Ibidem, s. 36.

104 Ibidem, s. 27-28.

105 Ibidem, s. 35-36. 
достояние? Кроме того был затронут вопрос советского оперативного и стратегического планирования накануне агрессии Третьего Рейха против СССР.

Особенное внимание уделено заседанию Главного Военного Совета и командного состава Красной Армии в декабре 1940 г. так как несколько докладов, прочитанных на этой встрече, разрешало спорные вопросы советского оперативного искусства. В своей работе автор пользуется м пр. опубликованными трудами советских военных этого периода, а также современных американских историков.

Перевод Агнешка Поспишьль

\section{Bibliografia}

Armia Czerwona w latach 1940-1941 (Materiały z posiedzenia Głównej Rady Wojennej i wyższej kadry dowódczej Armii Czerwonej w dniach 23-31 grudnia 1940 roku), wstęp, tłum. i oprac. J. Budziński, C. Grzelak, Z. Matuszak, Warszawa 2007.

Armia Czerwona w przededniu najcięższej próby (Materiały z posiedzenia Głównej Rady Wojennej i wyższej kadry dowódczej Armii Czerwonej w dniach 23-31 grudnia 1940 roku), wstęp, tłum. i oprac. J. Budziński, C. Grzelak, Z. Matuszak, Warszawa 2006.

Bieszanow W., Kadry decyduja o wszystkim, przeł. A. Palacz, Warszawa 2009.

Harrisom R. W., Architect of Sowiet Victory in Word War II. The Life and Theories of G. S. Isserson, Jefferson 2010.

Harrisom R. W., The Russian Way of War. Operational Art, 1904-1940, Lawrence 2001.

Иссерсон Г. С., Эволюиия оперативного искусства, Москва 1937.

Кен О., Мобилизационное планирование и Политические решения, Москва 2008.

Musiał B., Na zachód po trupie polski, przeł. M. Falkowski, Warszawa 2009.

На приеме у Сталина. Тетради (журналы) записей лии, принятых И. В. Сталиным (19241953 г2.), Москва 2008.

Naveh S., In Pursuit of Military Excellence. The Evolution of Operational Theory, Londyn 2004.

Sołonin M., 22 czerwca 1941 czyli jak zaczęła się Wielka Wojna Ojczyźniana, przeł. T. Lisiecki, Poznań 2007.

Sołonin M., 23 czerwca. Dzień „M”, przeł. J. Redlich, Poznań 2008.

Sołonin M., 25 czerwca. Głupota czy agresja?, przeł. J. Redlich, Poznań 2011.

Sołonin M., Nic dobrego na wojnie, przeł. A. Pawłowska, Poznań 2011.

Suworow W., Lodołamacz, przeł. A. Mietkowski, Piotr Halbersztat, Poznań 2008.

Reese R. R., Czerwoni Dowódcy. Korpus Oficerski Armii Czerwonej, przeł. S. Kędzierski, Warszawa 2010.

Reese R. R., The Soviet Military Experience. A history of Soviet Army 1917-1991, Routledge 2000. Россия - ХХ век. Документы. 1941 г., Москва 1998.

Триандафиллов В. К., Характер операций современных армий, Москва 1936.

Wieczorkiewicz P., Łańcuch śmierci. Czystka w Armii Czerwonej 1937-1939, Warszawa 2001.

Sebastian Chojnacki - ukończył studia magisterskie na kierunku historia na Uniwersytecie Jagiellońskim. Zajmuje się historią wojskowości XIX i I połowy XX wieku. Mieszka w Krakowie. 